\title{
Atmospheric deposition chemistry in a subalpine area of the Julian Alps, North-West Slovenia
}

\author{
Gregor MURI* \\ Slovenian Environment Agency, Vojkova 1b, 1000 Ljubljana, Slovenia \\ *Corresponding author: gregor.muri@zzv-kr.si
}

\begin{abstract}
Wet-only precipitation was collected in Rateče, a remote village in the outskirts of the Julian Alps (Nort-West Slovenia) during 20032011, in order to characterise atmospheric deposition chemistry. The samples were collected on a daily basis and combined into weekly samples that were analysed for $\mathrm{pH}$, conductivity and major anions and cations. Ammonium, nitrate and sulphate were the most abundant ions, exhibiting volume-weighted mean values (2003-2011) of 22, 17 and $17 \mu e q L^{-1}$, respectively. Furthermore, the trends of the major parameters in the precipitation were assessed using a simple linear regression. A significant downward trend of both nitrate and sulphate was observed, explained by evident reductions in $\mathrm{NO}_{x}$ and $\mathrm{SO}_{x}$ emissions in the region. The decline of nitrate and sulphate was also reflected in a significant and downward trend of conductivity. While the trend of ammonium could also be downward, the trends of other major ions were not significant. Atmospheric nitrogen deposition, representing inorganic forms of nitrogen (1.e., ammonium and nitrate), was calculated to examine potential threats that the deposition of nitrogen may cause on lake ecosystems. Nitrogen deposition in Rateče ranged from 5.5 to $9.5 \mathrm{~kg} \mathrm{~N} \mathrm{ha}^{-1} \mathrm{yr}^{-1}$. Although this was below the critical threshold that might cause an impact on surface waters, nitrogen deposition in the nearby Julian Alps, where sensitive mountain lakes are situated, might be higher and its impact on the ecosystem greater. In fact, several studies performed on water chemistry, sedimentary organic matter and stable isotopes in Slovenian mountain lakes have shown progressive changes in their water columns and sediments that can be attributed to nitrogen deposition.
\end{abstract}

Key words: precipitation, trends, nitrogen deposition, Triglav National Park.

Received: November 2012. Accepted: January 2013.

\section{INTRODUCTION}

In the $1970 \mathrm{~s}$, acid rain, i.e. the deposition of acidic sulphur and nitrogen compounds, was found to be affecting the state of terrestrial and aquatic ecosystems in conditions of low buffering capacity all over the world. Surface waters became acidified due to high loads of sulphur and nitrogen, which resulted in changes of water chemistry, such as $\mathrm{pH}$ value, acid-neutralising capacity and a significant decrease in base cation concentration, as well as in changes in the biological community and fish extinction (Momen et al., 2006; Skjelkvåle et al., 2005; Marchetto et al., 2004; Clow et al., 2003). This process was most evident in areas where bedrock has limited buffering capacity. Because surface water acidification has been recognised as one of the major environmental problems in many parts of the world, international and national emission control programmes have been initiated. Initially, only sulphur emissions have been regulated, while nitrogen emission control has started later. As a result, sulphur emissions have decreased significantly, for instance by $82 \%$ across the EU-27 area in the period 1990-2010 (EEA, 2012). In the same period, nitrogen emission levels across the EU-27 decreased by $47 \%$ (EEA, 2012). Reductions in sulphur and nitrogen emission have resulted in a significant decrease in acidification of surface waters and a subsequent slow and/or limited recovery of aquatic ecosystems. Initially, it was thought that aquatic ecosystems would recover quickly after the decrease of atmospheric loads of sulphur and nitrogen; however, this was not the case. It was found that biological recovery was characterised by substantial lag times and hysteresis; the path of biological recovery is not the reverse of the path of acidification (Wright and Cosby, 2003). Furthermore, it was demonstrated that it is not just the deposition of sulphur and nitrogen that is important for the state of aquatic ecosystems but also other processes, such as transformations in catchment soil, climate effect, nitrogen leaching, sulphate desorption from soils and Saharan dust deposition (Camarero et al., 2004, 2009; Kopacek et al., 2005; Wright et al., 1998).

Nitrogen is also able to enter biogeochemical cycles, and subsequently it could impact ecosystems. Until the nitrogen retention capacity of an ecosystem is exceeded, atmospheric input of nitrogen might not result in altered nutrient imbalances, biological changes or increased sensitivity to other stress factors, at least for some time (Rogora et al., 2006). However, steady and/or high nitrogen loads cause nitrogen saturation of an ecosystem in the course of time. In the worst stage, an ecosystem is no longer able to retain all inputs of nitrogen as the availabil- 
ity of nitrogen exceeds plant and microbial nutritional demand (Aber et al., 1989). Furthermore, changes in nitrogen cycling occur and progress through stages. The most obvious results of these stages are altered seasonal and long-term patterns of nitrate in surface waters (Stoddard et al., 2001; Dise and Wright, 1995; Traaen and Stoddard, 1995). For instance, Stoddard et al. (2001) observed a clear coherence between atmospheric nitrogen deposition and nitrogen saturation stages at European ICP Waters sites. Above the empirically-determined deposition limit of $10 \mathrm{~kg} \mathrm{~N} \mathrm{ha}^{-1} \mathrm{yr}^{-1}$, there was increasing evidence of nitrogen saturation. Nevertheless, it is important to state that other factors, such as soil chemistry and climate, also affect the stage of nitrogen saturation.

The goal of this paper is to assess temporal trends in precipitation and the extent of atmospheric nitrogen deposition in Rateče, a small and remote village situated in the outskirts of the protected area of the Julian Alps (North-West Slovenia). During 2003-2011, daily wet-only precipitation samples were collected and combined into weekly samples that were subsequently analysed for major chemical parameters, i.e. $\mathrm{pH}$, conductivity and major anions and cations. The trends of major parameters in the precipitation were assessed and the impact of nitrogen deposition on the nearby mountain lakes was discussed in detail to examine the potential threats that depositing nitrogen might cause on nitrogen cycling in these fragile ecosystems; this aspect is particularly important for the future state of most alpine lakes in the Julian Alps. Overall, atmospheric deposition data collected in remote areas represent a valuable tool for assessing and understanding the extent of human impact on remote ecosystems.

\section{METHODS}

\section{Site description and sampling}

Precipitation was sampled at the permanent meteorological station located in Rateče ( $46^{\circ} 29^{\prime} 51^{\prime \prime} \mathrm{N}, 13^{\circ} 43^{\prime}$ 03 " E). Rateče is a small village in a remote alpine valley in North-West Slovenia (Fig. 1). Its elevation is $864 \mathrm{~m}$. The predominant bedrock in the area is Triassic limestone

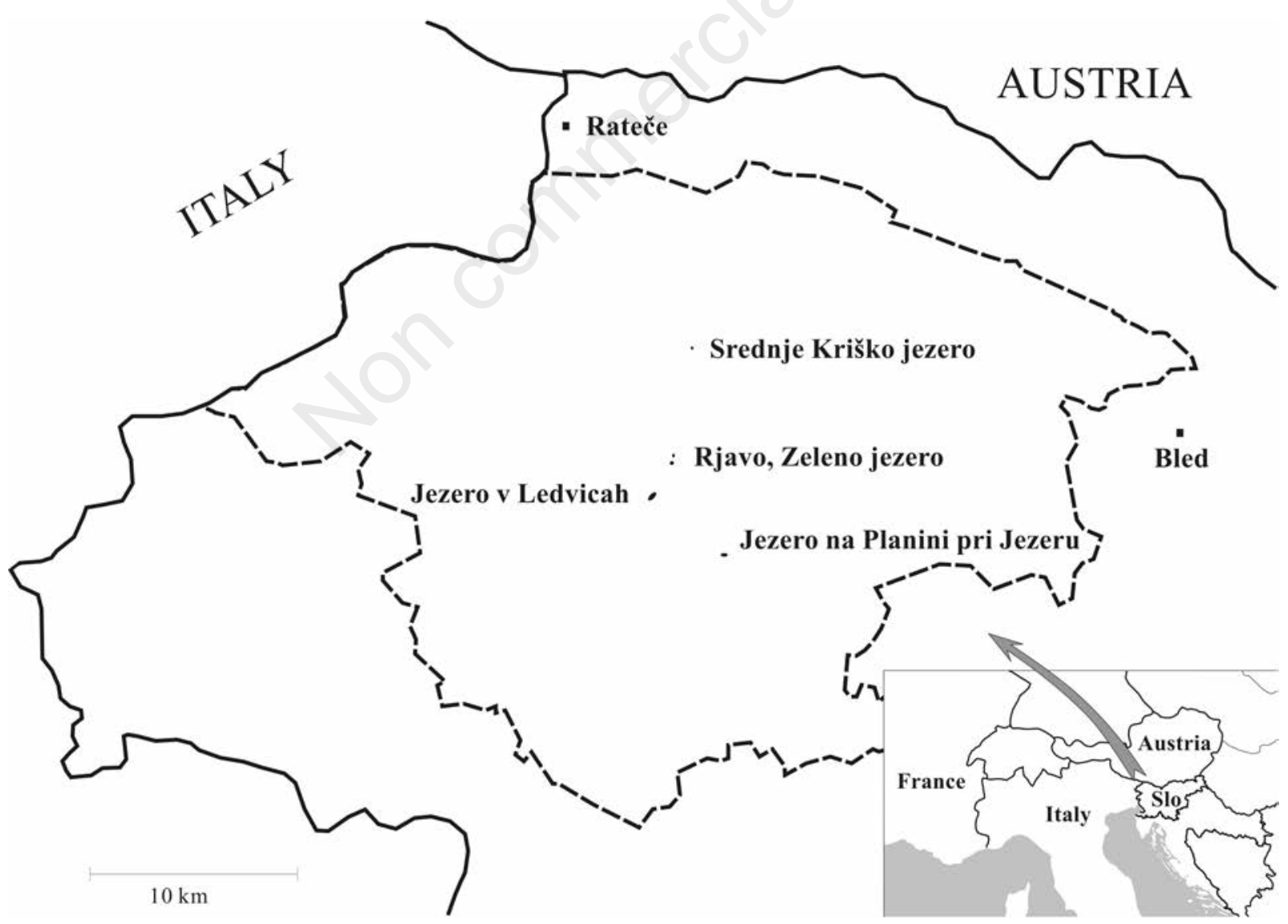

Fig. 1. Geographical position of the sampling site (the dashed line represents the border of the Triglav National Park). 
and dolomite, but in the northern part of the valley upper Palaeozoic clastic and carbonate rocks are also present. There are pastures at the bottom of the valley, while the slopes are covered with conifer forests up to 1600-1800 $\mathrm{m}$. The climate of the region has the main characteristics of alpine climate. Two precipitation maxima are generally observed. The more pronounced is commonly observed in autumn (September through November) and the lower in late spring/early summer (April through June), while the winter months tend to be the driest (SEA, 2006). The sampling site in Rateče has been included in the monitoring network of atmospheric deposition in Slovenia since 2003. The station is located away from any direct sources of emissions and mainly receives only long-range atmospheric pollution. In addition, it is located only $2 \mathrm{~km}$ away from the border of the protected area of the Julian Alps: the Triglav National Park (Fig. 1).

Srednje Kriško jezero, Rjavo jezero, Zeleno jezero, Jezero $v$ Ledvicah and Jezero na Planini pri Jezeru are all remote mountain lakes situated in the Julian Alps. Their geographical locations are presented in Fig. 1, and morphological and selected water chemistry and sedimentary characteristics are summarised in Tab. 1. All the lakes are of glacial origin, relatively small and shallow and surrounded by steep slopes. Jezero na Planini pri Jezeru is located below the local tree line, while the other lakes are above it. The lakes are covered with ice from at least five to up to eight months per year (Brancelj, 2002). The lakes are located in the protected area of the Triglav National Park, and as such anthropogenic activities in the park are relatively limited. The lakes situated above the local tree line are still in relatively pristine condition and were rated as oligo/mesotrophic, while the condition of Jezero na Planini pri Jezeru has deteriorated due to increased inputs of nutrients from its watershed and the lake was rated as eutrophic (Vreča and Muri, 2006; Muri, 2004).

Wet-only precipitation was collected on a daily basis by an automatic, thermally insulated sampler (NSA 181/S; Eigenbrodt GmbH \& Co., Königsmoor, Germany). The rain sampler consisted of a $25 \mathrm{~cm}$ diameter funnel connected to one of eight $1 \mathrm{~L}$ plastic bottles. In the laboratory, all daily samples of one week (Monday to Sunday) were combined proportionally to the rain amount into one weekly sample that was stored at $4^{\circ} \mathrm{C}$ until further analysis.

\section{Chemical analyses}

Standard laboratory procedures according to the respective ISO standards $(1985,1994,1998,2007)$ were followed when analysing precipitation samples. Chemical analyses were carried out only in the samples with more than $20 \mathrm{~mL}$ of precipitation. The $\mathrm{pH}$ was measured electrometrically by a pH 540 GLP instrument (WTW Wissenschaftlich-Technische Werkstätten $\mathrm{GmbH}$, Weilheim, Germany; equipped with a SenTix H glass electrode). Conductivity was also measured electrometrically by a CDM 230 instrument (Radiometer Analytical SAS, Villeurbanne, France) and reported at the reference temperature of $25^{\circ} \mathrm{C}$. The major anions and cations were determined chromatographically, using a DX 120 (Dionex, Sunnyvale, CA, USA) ion chromatograph for anions and a Waters 431 (Waters, Milford, MA, USA) ion chromatograph for cations. Both ion chromatographs were equipped with a conductivity detection cell. Anions (i.e., chloride, nitrate and sulphate) were determined on an IonPac AS14 separation column $(250 \times 4.0 \mathrm{~mm})$ followed by a chemical suppressor module. Cations (i.e., sodium, ammonium, potassium, calcium and magnesium) were determined on an IC-Pak Cation M/D separation column $(150 \times 3.9 \mathrm{~mm})$ without chemical suppression. Detection limits were in the range from 0.2 to $0.8 \mu \mathrm{eq} \mathrm{L}^{-1}$. Precision of ion chromatographic measurements, based on replicate analyses of real samples, was up to $5 \%$.

Blank and control sample analyses were performed to control analytical procedures. An ion charge balance and conductivity percentage differences were also performed. The results were finally evaluated according to the criteria established by the WMO GAW (2004).

Tab. 1. Basic morphological (Brancelj, 2002), selected water chemistry (Muri, 2004; Muri and Brancelj, 2003) and sedimentary (Vreča and Muri, 2010) characteristics of the lakes.

\begin{tabular}{lccccc}
\hline & SrKJ & RJ & ZJ & JL & JPJ \\
\hline Altitude (m) & 2150 & 2002 & 1983 & 1830 & 1430 \\
Surface Area (ha) & 0.66 & 1.34 & 0.61 & 2.19 & 1.56 \\
Max. Depth (m) & 9 & 10 & 3 & 15 & 11 \\
Catchment Area (ha) & 16 & 36 & 24 & 175 & 95 \\
Alkalinity ( $\mu$ eq L -1$)$ & $1250^{*}$ & $1390^{*}$ & $1070^{*}$ & $1410-1990$ & $1410-3550$ \\
Calcium $\left(\mu\right.$ eq L L $\left.^{-1}\right)$ & $1120^{*}$ & $1080^{*}$ & $749^{*}$ & $1040-1520$ & $1090-2980$ \\
Nitrate $(\mu$ eq L L & $7.3^{*}$ & $22.3^{*}$ & $2.8^{*}$ & $11.1-31.4$ & $0.7-19.7$ \\
$\delta^{15} \mathrm{~N}(\%)$ & $-1.9-2.3$ & $-3.3--0.2$ & $-2.3-0.6$ & $-3.4-2.1$ & $1.1-2.4$ \\
\hline
\end{tabular}

$S r K J$, Srednje Kriško jezero; $R J$, Rjavo jezero; $Z J$, Zeleno jezero; $J L$, Jezero v Ledvicah; $J P J$, Jezero na Planini pri Jezeru.

*Average value, since the lake was sampled only once per year. 


\section{Statistical analysis}

Several statistical techniques, such as non-parametric (the Mann-Kendall test and the Seasonal Kendall test) and parametric techniques (a simple linear regression) are generally used to analyse temporal trends of data such as those presented here (Marchetto et al., 2013). By conducting numerical simulations, Marchetto et al. (2013) determined that the longer the time series, the greater the trend slope and the lower the variability of the data, the more comparable are the three above-mentioned statistical techniques. Nevertheless, when applying these techniques to real data, they still concluded that the Seasonal Kendall test exhibited the highest power among all three techniques. Although non-parametric techniques are thus the more suitable, simple linear regression has also been employed in similar studies, such as those in the ICP Waters programme. In this study, a simple linear regression was applied to volumeweighted mean annual values of determinants in order to assess their trends during the period 2003-2011. Potassium was not included in the analysis, as its concentrations were below the limit of quantification for most of the time. A two-sided t-test was calculated for all other parameters with the null hypothesis that the slope equals zero, i.e. no trend is present. The null hypothesis was rejected for $\mathrm{P}$ values below 0.05 (ICP Waters, 2003).

\section{RESULTS}

Marked variability in the monthly distribution of precipitation amount collected in Rateče during 2003-2011 was observed. Monthly amounts of precipitation ranged from 10 to $300 \mathrm{~mm}$ (data not shown) with the median value of $101 \mathrm{~mm}$. Annual rainfall ranged from 970 to $1659 \mathrm{~mm}$ with the average value of $1308 \mathrm{~mm}$ (Tab. 2). The average annual rainfall was thus lower than that of the reference period 1971-2000 (1474 mm; MOP, 2003b). In 2003, 2005-2007, 2009 and 2011, annual rainfall amounted to 66 to $92 \%$ of the reference annual rainfall. In 2008 and 2010, the reference value was exceeded by 6 and $13 \%$, respectively, and in 2004 , the annual rainfall was equal to that of the reference value.

$\mathrm{pH}$ ranged from 4.1 to 6.9 during the experimental period 2003-2011. Approximately half of all measurements were observed in the range of 5.1 to 5.8, exhibiting a median of 5.4 (data not shown). Sixty four percent of all samples were acidic $(\mathrm{pH}<5.6)$. Conductivity ranged from 2.0 (limit of detection) to $80 \mu \mathrm{S} \mathrm{cm} \mathrm{cm}^{-1}$ (Fig. 2). Nevertheless, most values were rather low; from 5.7 to $12 \mu \mathrm{S} \mathrm{cm}^{-1}\left(25^{\text {th }}\right.$ and $75^{\text {th }}$ percentile, respectively), with a median of $8.2 \mu \mathrm{S}$ $\mathrm{cm}^{-1}$, which is slightly above the volume-weighted mean value for the period 2003-2011 (8.0 $\mu \mathrm{S} \mathrm{cm}^{-1}$; Tab. 2).

The relative abundance of ions in precipitation decreased in order from ammonium to nitrate, sulphate, calcium, chloride, hydrogen ion, sodium, magnesium and potassium (Tab. 2). Ammonium, nitrate, sulphate and calcium dominated, whilst the other ions had lower concentrations by approximately one order of magnitude. While ammonium was the most abundant cation overall, it was also the parameter that varied most in absolute terms, followed by calcium (Fig. 2). The maximum concentration of ammonium amounted to $425 \mu \mathrm{eq} \mathrm{L}^{-1}$. The $25^{\text {th }}$ to $75^{\text {th }}$ percentile range included concentrations from 11 to 38 $\mu$ eq $\mathrm{L}^{-1}$, respectively, with a median of $22 \mu \mathrm{eq} \mathrm{L}^{-1}$, which also corresponded to the volume-weighted mean for the period 2003-2011. The maximum concentration of calcium amounted to $233 \mu \mathrm{eq} \mathrm{L}^{-1}$, but mostly ranged from 5.4 to $22 \mu \mathrm{eq} \mathrm{L} \mathrm{L}^{-1}$. The median of $11 \mu \mathrm{eq} \mathrm{L}^{-1}$ was however remarkably lower than the volume-weighted mean (20032011) of $15 \mu \mathrm{eq} \mathrm{L}{ }^{-1}$. Hydrogen ion, sodium, magnesium and potassium were among the least abundant cations,

Tab. 2. Annual rainfall volume, volume-weighted mean annual concentrations, volume-weighted mean values and trends with corresponding trend slopes in precipitation, as well as nitrogen deposition in Rateče (North-West Slovenia) during the period $2003-2011$.

\begin{tabular}{|c|c|c|c|c|c|c|c|c|c|c|c|c|}
\hline Year & $\begin{array}{l}\text { Rainfall } \\
\text { (mm) }\end{array}$ & $\begin{array}{c}\mathrm{H}^{+} \\
\left(\mu \mathrm{eq} \mathrm{L}^{-1}\right)\end{array}$ & $\begin{array}{c}\text { Cond. } \\
\left(\mu \mathrm{S} \mathrm{cm}^{-1}\right)\end{array}$ & $\begin{array}{c}\mathrm{NH}_{4}^{+} \\
\left(\mu \mathrm{eq} \mathrm{L} \mathrm{L}^{-1}\right)\end{array}$ & $\begin{array}{c}\mathrm{Ca}^{2+} \\
\left(\mu \mathrm{eq} \mathrm{L}^{-1}\right)\end{array}$ & $\begin{array}{c}\mathrm{Mg}^{2+} \\
\left(\mu \mathrm{eq} \mathrm{L} \mathrm{L}^{-1}\right)\end{array}$ & $\begin{array}{c}\mathrm{K}^{+} \\
\left(\mu \mathrm{eq} \mathrm{L}^{-1}\right)\end{array}$ & $\begin{array}{c}\mathrm{Na}^{+} \\
\left(\mu \text { eq } \mathrm{L}^{-1}\right)\end{array}$ & $\begin{array}{c}\mathrm{Cl}^{-} \\
\left(\mu \mathrm{eq} \mathrm{L}^{-1}\right)\end{array}$ & $\begin{array}{c}\mathrm{NO}_{3}^{-} \\
\left(\mu \text { eq } \mathrm{L}^{-1}\right)\end{array}$ & $\begin{array}{c}\mathrm{SO}_{4}{ }^{2-} \\
\left(\mu \mathrm{eq} \mathrm{L}^{-1}\right)\end{array}$ & $\begin{array}{c}\mathrm{N} \text { dep. } \\
\left(\mathrm{kg} \mathrm{N} \mathrm{ha}^{-1} \mathrm{yr}^{-1}\right)\end{array}$ \\
\hline 2003 & 970 & 6.66 & 11.1 & 28.6 & 16.5 & 4.26 & 0.89 & 5.54 & 6.53 & 22.1 & 22.7 & 6.9 \\
\hline 2004 & 1472 & 4.71 & 8.81 & 26.1 & 13.0 & 2.62 & 0.70 & 3.19 & 3.87 & 20.2 & 18.4 & 9.5 \\
\hline 2005 & 1201 & 4.95 & 8.93 & 18.7 & 22.9 & 7.24 & 0.53 & 2.61 & 6.57 & 16.5 & 18.6 & 5.9 \\
\hline 2006 & 1133 & 7.36 & 8.21 & 20.7 & 11.0 & 3.23 & 0.56 & 7.11 & 7.33 & 19.0 & 16.6 & 6.3 \\
\hline 2007 & 1159 & 6.12 & 8.88 & 24.4 & 17.1 & 3.65 & 0.88 & 4.05 & 4.67 & 20.0 & 21.6 & 7.2 \\
\hline 2008 & 1561 & 4.12 & 8.28 & 26.5 & 18.6 & 5.38 & 1.57 & 8.28 & 9.19 & 15.4 & 15.1 & 9.2 \\
\hline 2009 & 1356 & 3.82 & 7.51 & 22.0 & 16.1 & 3.13 & 0.76 & 4.12 & 5.14 & 16.3 & 15.9 & 7.3 \\
\hline 2010 & 1659 & 5.23 & 5.39 & 12.3 & 8.8 & 2.35 & 0.81 & 3.13 & 2.77 & 11.3 & 9.7 & 5.5 \\
\hline 2011 & 1264 & 4.17 & 6.38 & 18.2 & 10.7 & 2.61 & 0.97 & 3.30 & 3.45 & 14.1 & 14.7 & 5.7 \\
\hline Average $^{*}$ & 1308 & 5.12 & 7.99 & 21.7 & 14.8 & 3.77 & 0.87 & 4.57 & 5.43 & 16.9 & 16.6 & 7.1 \\
\hline Trend $^{*}$ & ns & $\mathrm{ns}$ & $\begin{array}{l}\downarrow(-0.53) \\
\mathrm{P}<0.01\end{array}$ & $\begin{array}{l}\downarrow(-1.2) \\
\mathrm{P}<0.1\end{array}$ & ns & $\mathrm{ns}$ & nd & ns & ns & $\begin{array}{l}\downarrow(-1.0) \\
\mathrm{P}<0.01\end{array}$ & $\begin{array}{l}\downarrow(-1.1) \\
\mathrm{P}<0.05\end{array}$ & $\mathrm{~ns}$ \\
\hline
\end{tabular}

Cond., conductivity (at $\left.25^{\circ} \mathrm{C}\right) ; \mathrm{N}$ dep., nitrogen deposition; $n$, not significant; $n d$, not determined. ${ }^{*}$ Average/trend for the period $2003-2011$; $\downarrow$ downward trend (the value in brackets represents the trend slope). 
with median values ranging from 1 to $4 \mu \mathrm{eq} \mathrm{L}^{-1}$, volumeweighted means (2003-2011) from 1 to $5 \mu \mathrm{eq} \mathrm{L^{-1 }}$ and maximum concentrations of 74, 93, 61 and $34 \mu \mathrm{eq} \mathrm{L} \mathrm{L}^{-1}$, respectively. Concentrations of anions varied less in absolute terms compared with cations. Nitrate and sulphate were the most abundant anions. The highest concentration observed for the former amounted to $296 \mu \mathrm{eq} \mathrm{L} \mathrm{L}^{-1}$ and for the latter to $170 \mu \mathrm{eq} \mathrm{L}^{-1}$. The $25^{\text {th }}$ to $75^{\text {th }}$ percentile concentrations were again much lower but very similar for both anions; they ranged from 12 to $31 \mu \mathrm{eq} \mathrm{L}^{-1}$ for nitrate

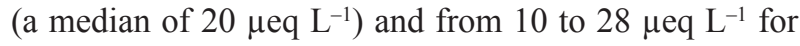
sulphate (a median of $17 \mu$ eq $\mathrm{L}^{-1}$ ). The volume-weighted mean values for the period 2003-2011 amounted to $17 \mu \mathrm{eq}$ $\mathrm{L}^{-1}$ for both anions. Overall levels of chloride were low, exhibiting a median of $4 \mu \mathrm{eq} \mathrm{L}^{-1}$, a volume-weighted mean (2003-2011) of $5 \mu \mathrm{eq} \mathrm{L} \mathrm{L}^{-1}$ and a maximum value of $76 \mu$ eq L $\mathrm{L}^{-1}$.

Volume-weighted mean annual concentrations of all major parameters in precipitation exhibited downward trends (Tab. 2; Fig. 3). Nevertheless, only the trends of conductivity $(\mathrm{P}<0.01)$, nitrate $(\mathrm{P}<0.01)$ and sulphate $(\mathrm{P}<0.05)$ were significant, while the trend of ammonium was only weakly significant $(\mathrm{P}<0.1)$. The rates of concentration decline per year for the period 2003-2011 amounted to approximately $0.5 \mu \mathrm{S} \mathrm{cm}^{-1} \mathrm{yr}^{-1}$ for conductivity and approximately to $1 \mu \mathrm{eq} \mathrm{L}^{-1} \mathrm{yr}^{-1}$ for ammonium, nitrate and sulphate (Tab. 2).

Nitrogen deposition was calculated by summing the volume-weighted mean annual concentrations of ammo- nium and nitrate and multiplying the sum with the corresponding annual rainfall volume. Nitrogen deposition from precipitation in Rateče ranged from 5.5 to $9.5 \mathrm{~kg} \mathrm{~N}$ $\mathrm{ha}^{-1} \mathrm{yr}^{-1}$ during 2003-2011, while the average value amounted to $7.1 \mathrm{~kg} \mathrm{~N} \mathrm{ha}^{-1} \mathrm{yr}^{-1}$ (Tab. 2).

\section{DISCUSSION}

\section{Atmospheric deposition chemistry}

Rateče is a remote subalpine village and thus longrange atmospheric transport is thought to be the main source of pollutants. Nevertheless, occasional high ammonium concentrations (Fig. 2) suggest that some local disturbance might also be present, such as agricultural activities. In general, the wet year 2010 was characterised by lower volume-weighted mean annual concentrations of most parameters, while mostly higher concentrations were observed in the dry year 2003 (Tab. 2). However, the relationships are not just straightforward, suggesting that other factors are also important, such as the direction from which air masses of different types of pollution arrive over the study area. Furthermore, the volume-weighted mean monthly concentrations of most parameters exhibited higher concentrations in warmer periods of the year (Fig. 3), due to the transport of compounds at higher altitudes (Barbieri and Mosello, 2000). In contrast, hydrogen ion concentration tends to be highest in the winter months resulting in lower $\mathrm{pH}$. Lower $\mathrm{pH}$ of precipitation in winter could be caused by higher concentrations of acidic nitrate

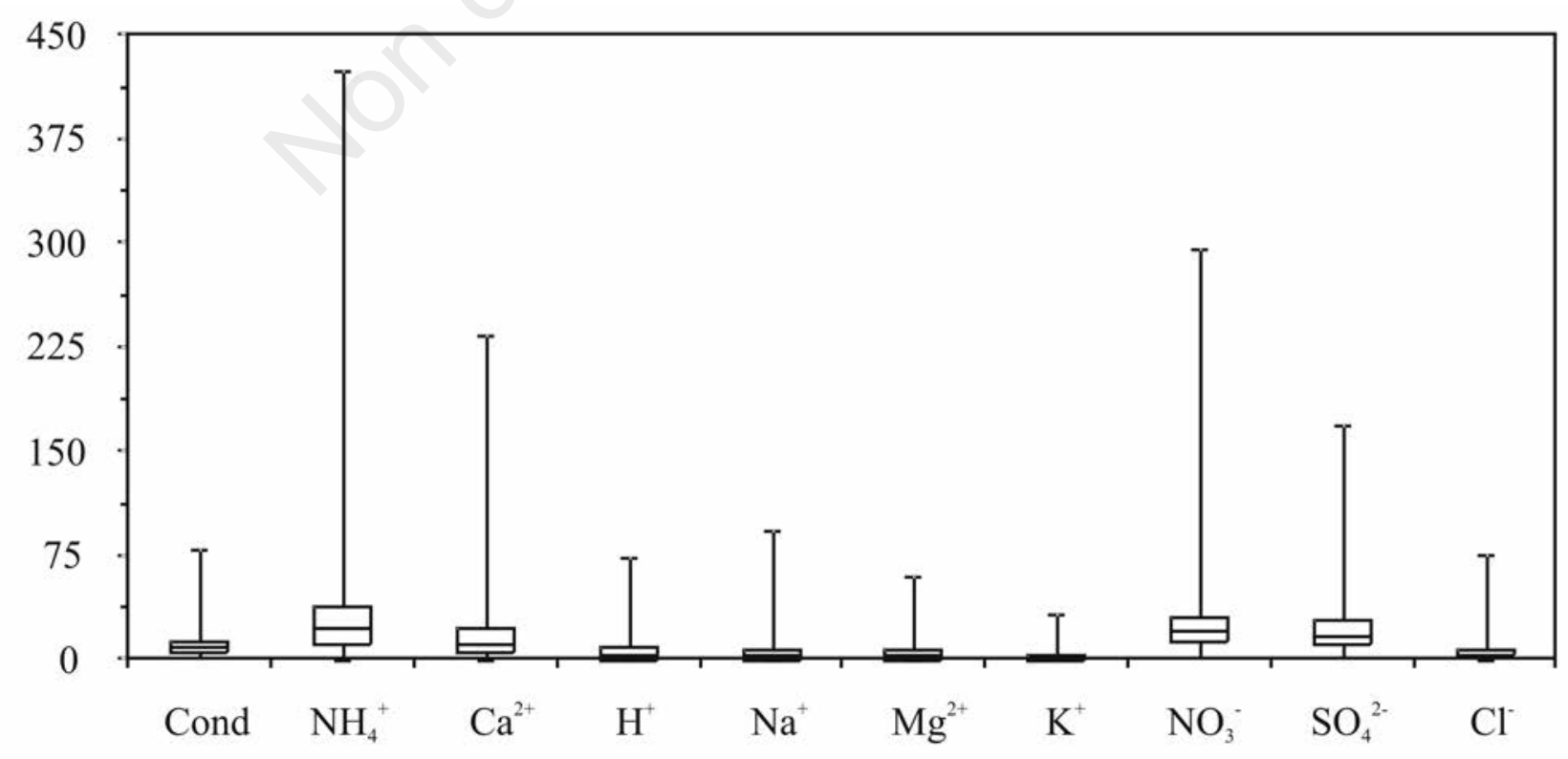

Fig. 2. Weekly conductivity $\left(\mu \mathrm{S} \mathrm{cm}^{-1}\right.$, at $25^{\circ} \mathrm{C}$ ) and major ion concentrations ( $\mu \mathrm{eq} \mathrm{L}^{-1}$ ) in precipitation in Rateče in the period 20032011 (whiskers: minimum and maximum values; boxes: $25^{\text {th }}$ and $75 t^{\mathrm{h}}$ percentiles; thick horizontal line: median value). 


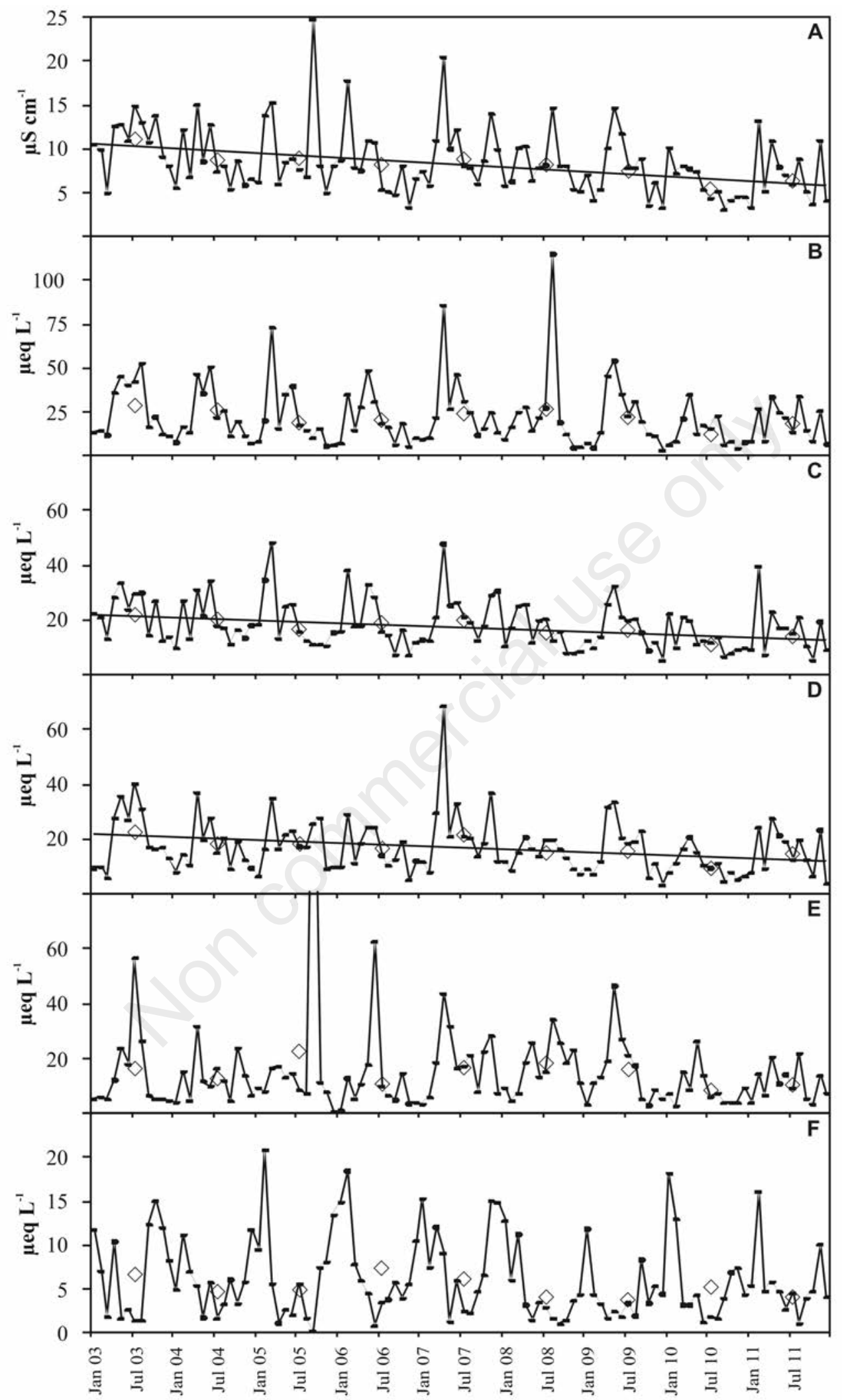

Fig. 3. Volume-weighted mean monthly (lines) and annual (open squares) values of A) conductivity, B) ammonium, C) nitrate, D) sulphate, E) calcium and F) hydrogen ion in precipitation in Rateče in the period 2003-2011 (a regression line is added if the trend is significant; $\mathrm{P}<0.05)$. 
and sulphate; however, these ions exhibited lower concentrations in winter (Fig. 3), which suggests the reverse. On the other hand, a comparison of seasonal calcium and hydrogen ion concentrations showed that the highest hydrogen ion concentrations (i.e., the lowest $\mathrm{pH}$ ) were associated with the lowest calcium concentrations (Fig. 3), suggesting that the winter decrease in calcium is greater than that of nitrate and sulphate, resulting in lower $\mathrm{pH}$ of precipitation. High calcium concentrations $\left(>100 \mu \mathrm{eq} \mathrm{L} \mathrm{L}^{-1}\right)$ associated with $\mathrm{pH}$ values $>6$ were occasionally observed in spring and summer. These events can be attributed to episodes of mineral dust transport, which have been observed in this part of Europe (Barbieri and Mosello, 2000; Tait and Thaler, 2000). For the dates associated with these particular events, the DREAM8b model (Basart et al., 2012) at the Barcelona Supercomputing Center indeed predicted higher concentrations of mineral dust in the atmosphere over the study area. Sodium concentration was occasionally higher than hydrogen ion. In these particular cases, chloride was almost equally as high as sodium. The events with high sodium and chloride can be attributed to marine influences. The studied area is approximately 85 $\mathrm{km}$ to the north of the Adriatic sea. The prevailing winds in the area that bring humid and relatively warm air masses to the orographic barrier, i.e. the Julian Alps, where precipitation is the most intense, are south-westerlies (SEA, 2006) and thus, periodic episodes of marine impact on the studied area are to be expected. To estimate the fraction of anthropogenic $v_{s}$ sea-salt sulphate in precipitation, the theoretical sea-salt ratio of sulphate to chloride (i.e., 0.103:1) was used (UBA, 2004). Furthermore, it was assumed that anthropogenic sources of chloride are negligible and thus, all chloride in precipitation would be of marine origin. Non sea-salt sulphate strongly prevailed. Sea-salt sulphate generally contributed only approximately $5 \%$ to the total sulphate concentration. Nevertheless, its contribution increased up to $10 \%$ a few times per year, while on rare occasions in the period 2003-2011 sea-salt sulphate accounted for 20 to $25 \%$ of the total sulphate concentration. Therefore, it can be concluded that the predominant source of sulphate in precipitation is anthropogenic. The small influence of sea-salt on precipitation in the northern part of the Julian Alps is further supported by low median and mean concentrations of sodium and chloride.

\section{Assessment of trends}

Downward trends of nitrate and sulphate in precipitation can be explained by decreased emissions of these two pollutants to the atmosphere due to international and national emission control programmes and were also frequently observed in other studies on precipitation chemistry (Marchetto et al., 2013; Aherne et al., 2010; Rogora et al., 2006; Lehmann et al., 2005; Civerolo et al., 2003; Tait and Thaler, 2000). $\mathrm{SO}_{\mathrm{x}}$ emissions in Slovenia decreased steadily since the beginning of the 1990s. In the period 2003-2010, an 84\% decrease was observed (EEA, 2012). $\mathrm{SO}_{\mathrm{x}}$ emissions in neighbouring western countries, i.e. Italy and Austria, are also important in addition to Slovenian sources, because their atmospheric pollutants can be transported to Slovenia via long-range transport (MOP, 2003a). According to EEA (2012), $\mathrm{SO}_{x}$ emissions in Italy and Austria also decreased in the period 2003-2010 but the declines were not as steep as in Slovenia, amounting to 60 and $41 \%$, respectively. Therefore, the declining $\mathrm{SO}_{\mathrm{x}}$ emissions in Slovenia and neighbouring countries explains the significant $(\mathrm{P}<0.05)$ downward trend of sulphate in precipitation. However, the rate of sulphate decline in precipitation per year in Rateče $\left(\sim 1 \mu \mathrm{eq} \mathrm{L}^{-1} \mathrm{yr}^{-1}\right)$ tends to be a bit lower than those at other sampling sites in the Alps, where declines of $\sim 1.5 \mu \mathrm{eq} \mathrm{L} \mathrm{L}^{-1} \mathrm{yr}^{-1}$ were observed during a similar time span (1998-2010; Marchetto et al., 2013). In contrast, the reduction in $\mathrm{NO}_{\mathrm{x}}$ emissions in Slovenia was less evident, especially in the most recent period. Only an approximate $10 \%$ decrease was observed during the years 2003-2010 (EEA, 2012) but $\mathrm{NO}_{\mathrm{x}}$ emissions also exhibited episodic increases during this time span. On the other hand, $\mathrm{NO}_{\mathrm{x}}$ emissions in Italy and Austria decreased more remarkably, by 27 and $19 \%$, respectively (EEA, 2012). Therefore, declining $\mathrm{NO}_{\mathrm{x}}$ emissions around the study area support the significant $(\mathrm{P}<0.01)$ downward trend of nitrate observed in Rateče, while the rate of nitrate decline per year seems to be a bit higher than the values reported by Marchetto et al. (2013) for the Alps: $\sim 1$ vs $\sim 0.6$ $\mu$ eq $\mathrm{L}^{-1} \mathrm{yr}^{-1}$, respectively. The reduction in ammonia emissions in Slovenia was quite low in 2003-2010, amounting to approximately $11 \%$. A similar reduction was also observed in Italy, while in Austria it was even lower, at 3\% (EEA, 2012). These declines in ammonia emissions could be reflected in a downward trend of ammonium in precipitation, but the trend was only weakly significant $(\mathrm{P}<0.1)$. The trend slope in Rateče amounted to $\sim 1 \mu \mathrm{eq} \mathrm{L}{ }^{-1} \mathrm{yr}^{-1}$, while declines of approximately $0.7 \mu \mathrm{eq} \mathrm{L} \mathrm{L}^{-1} \mathrm{yr}^{-1}$ were reported elsewhere in the Alps (Marchetto et al., 2013). In accordance with the significant downward trends of nitrate and sulphate - the two abundant ions in precipitation - a significant $(\mathrm{P}<0.01)$ downward trend of conductivity was observed. Decreasing concentrations of major ions in precipitation should result in the decline of conductivity. Similarly, downward trends of acidic nitrate and sulphate should overcome the decline in basic ammonium and calcium, resulting in higher $\mathrm{pH}$ (i.e., lower hydrogen ion concentration) of precipitation, which was observed in Rateče though the trend was not significant.

\section{Atmospheric nitrogen deposition and its impact on Slovenian mountain lakes}

The average nitrogen deposition in Rateče amounted to $7.1 \mathrm{~kg} \mathrm{~N} \mathrm{ha}^{-1} \mathrm{yr}^{-1}$ in the period 2003-2011 (Tab. 2), 
which was in a good agreement with the value that Mosello et al. (2002) reported for the neighbouring Friuli Venezia Giulia region of Italy during 1998-1999 $(7.3 \mathrm{~kg}$ $\mathrm{N} \mathrm{ha}^{-1} \mathrm{yr}^{-1}$ ). In some years, nitrogen deposition in Rateče tends to be very close to the critical threshold of $10 \mathrm{~kg} \mathrm{~N}$ $\mathrm{ha}^{-1} \mathrm{yr}^{-1}$, which is believed to cause elevated concentrations of nitrate in surface waters (Stoddard et al., 2001; Dise and Wright, 1995). On the other hand, it is important to recall that the calculated nitrogen deposition represents only inorganic forms of nitrogen in wet form. Other forms of nitrogen, such as organic nitrogen and other deposition fluxes of inorganic nitrogen (e.g., dry deposition) were not addressed in this study but they would certainly add to the total. For instance, Mosello et al. (2002) showed that the total nitrogen deposition in the nearby Friuli Venezia Giulia region was $\sim 15-20 \%$ higher than the deposition of inorganic nitrogen alone. The impact of nitrogen deposition on ecosystems should be even more pronounced in the nearby central area of the Julian Alps, where several mountain lakes are situated. Mountain lakes are generally considered sensitive ecosystems (Battarbee et al., 2009). Their location is 12 to $25 \mathrm{~km}$ to the south of Rateče. It is reasonable to expect that nitrogen deposition in the high mountain areas of the Julian Alps would be higher than that in Rateče due to: i) precipitation amounts approximately twice as high (Kastelec, 1999), and ii) higher elevation and upwind direction that would change the composition of precipitation and thus could be above the critical threshold and closer to the value that Rogora et al. (2006) reported for the Central-Southern Alps (14$16 \mathrm{~kg} \mathrm{~N} \mathrm{ha}^{-1} \mathrm{yr}^{-1}$ ). Furthermore, it seems that nitrogen deposition in the whole southern rim of the European Alps is considerably higher than in some other mountain or remote areas of the world (Rogora et al., 2008), e.g. Northern Patagonia in the Andes, Svalbard islands, the Khumbu-Himal region of the Himalayas and the Serra da Estrela in continental Portugal, where depositions up to 7 $\mathrm{kg} \mathrm{N} \mathrm{ha}{ }^{-1} \mathrm{yr}^{-1}$ were observed.

The consequences that depositing nitrogen might cause to Slovenian remote mountain lakes were studied in several projects. In limnological studies, water chemistry dynamics in several Slovenian mountain lakes were studied. In Jezero $v$ Ledvicah, which is located above the local tree line with only bare rocks and some thin soils that support grasses in its watershed, nitrate concentration in the water column never dropped below $10 \mu$ eq L $\mathrm{L}^{-1}$ (Tab. 1; Muri, 2004; Muri and Brancelj, 2003). As reported by the same authors, the nitrate concentration in Jezero na Planini pri Jezeru, which is surrounded by extensive conifer forests ranged in contrast from the limit of detection $\left(0.7 \mu \mathrm{eq} \mathrm{L} \mathrm{L}^{-1}\right)$ to a few $\mu \mathrm{eq} \mathrm{L}^{-1}$ in the growing season and only occasionally exceeded $10 \mu \mathrm{eq} \mathrm{L} \mathrm{L}^{-1}$ (exhibiting maximum values of $\sim 20 \mu$ eq L ${ }^{-1}$; Tab. 1) during the rest of the year. Nitrate concentration in Jezero $v$ Ledvicah somehow fitted the range that Rogora et al. (2008) reported for the CentralSouthern Alps (a median of $\sim 15 \mu \mathrm{eq} \mathrm{L} \mathrm{L}^{-1}$ ), but was considerably higher than in some other parts of the world reported by the same authors, where nitrate concentration did not exceed $4 \mu \mathrm{eq} \mathrm{L} \mathrm{L}^{-1}$. Remarkably different nitrate concentrations in Jezero $v$ Ledvicah and Jezero na Planini pri Jezeru suggest that the levels of nitrogen saturation in the two watersheds are in contrast. To assess nitrogen saturation in the watersheds, the criteria of Traaen and Stoddard (1995) were applied. These criteria are generally used for ecosystems that are sampled monthly but can also be used for an approximate classification of ecosystems that are sampled just a few times per year, as was the case in Jezero $v$ Ledvicah and Jezero na Planini pri Jezeru. A saturation stage of 2 can be denoted for the former lake and of $0 / 1$ for the latter. The saturation stage of 2 means that more than two values of nitrate exceed $5 \mu \mathrm{eq} \mathrm{L}^{-1}$ in the growing season, but all concentrations are below $50 \mu \mathrm{eq} \mathrm{L}^{-1}$. In the saturation stage of $0 / 1$, more than one value of nitrate is below $3 \mu \mathrm{eq} \mathrm{L} \mathrm{L}^{-1}$, while the highest concentrations range from 10 to $20 \mu \mathrm{eq} \mathrm{L} \mathrm{L}^{-1}$ (Traaen and Stoddard, 1995). Finally, it is also important to mention that Jezero na Planini pri Jezeru is classified as eutrophic (Muri, 2004; Muri and Brancelj, 2003) and thus, exhibits a higher demand for nitrate by primary producers, resulting in further diminishment of nitrate concentrations in the water column.

Sedimentary organic matter and stable carbon and nitrogen isotopes in the mountain lakes were also studied. In the lakes that are located above the local tree line, i.e. Srednje Kriško jezero, Rjavo jezero, Zeleno jezero and Jezero $v$ Ledvicah, $\delta^{15} \mathrm{~N}$ values in the sediments (Tab. 1) have decreased considerably in the last $\sim 50$ years (based on age assessment from Jezero v Ledvicah sediment), which has been explained by changes in sources of nitrogen (Vreča and Muri, 2006, 2010). The authors also observed that coherent sedimentary nitrogen isotopic shifts were not always accompanied by synchronous shifts in $\delta^{13} \mathrm{C}_{\text {org }}$ and concluded that the nitrogen cycle in these lakes is influenced predominantly by ${ }^{15} \mathrm{~N}$-depleted dissolved inorganic nitrogen that mostly originates from atmospheric deposition (Talbot, 2001). In contrast, sedimentary $\delta^{15} \mathrm{~N}$ values in Jezero na Planini pri Jezeru varied only slightly in the time span represented by the core, with the values being close to the ones that were observed in the deepest (oldest) Jezero $v$ Ledvicah sediments (Tab. 1; Vreča and Muri, 2006).

\section{CONCLUSIONS}

Significant downward trends of nitrate $(\mathrm{P}<0.01)$ and sulphate $(\mathrm{P}<0.05)$ in precipitation were observed in Rateče during 2003-2011. These trends are in agreement with remarkable declines in $\mathrm{NO}_{\mathrm{x}}$ and $\mathrm{SO}_{\mathrm{x}}$ emissions that were observed all across the European Union. In accordance with the fact that the two ions are major con- 
stituents of conductivity, conductivity also exhibited a significant downward trend $(\mathrm{P}<0.01)$ in the studied period. While the trend of ammonium could also be downward $(\mathrm{P}<0.1)$ thus explaining weak declines of ammonium observed across the European Union, the trends of all other major ions were downward but not significant at a significance level of 0.05 .

It can only be speculated that nitrogen deposition in the central part of the Julian Alps, where several mountain lakes are located, could be higher than that observed in Rateče. Nevertheless, past studies on the limnology and sedimentary geochemistry of these lakes indicate that most of them are at risk. It seems that atmospheric nitrogen deposition in high mountain areas of Slovenia is close to or even exceeds the critical threshold, because the lakes that are located at higher elevations with only modest/no vegetation cover and thin soils, are not able to metabolise and/or immobilise all the nitrogen that is deposited from the atmosphere, which is reflected in elevated nitrate concentrations in the water columns and $\delta^{15} \mathrm{~N}$ shifts in the sediments. These observations suggest a particular sensitivity of these lakes to any external input, either atmospheric or terrestrial and indicate a potential threat for the future state of these ecosystems. In contrast, it seems that nitrogen cycling, despite its complexity, is relatively better regulated in ecosystems with thicker soils and abundant vegetation in the watershed, as indicated by the markedly lower nitrate concentrations in the water columns and relatively uniform sedimentary $\delta^{15} \mathrm{~N}$ values.

\section{ACKNOWLEDGMENTS}

Colleagues from the Chemical Analytical Laboratory are kindly acknowledged for their help in the laboratory and those from the Air Quality Sector for providing the data on precipitation. The suggestions of two anonymous reviewers greatly improved the quality of this manuscript.

\section{REFERENCES}

Aber JD, Nadelhoffer KJ, Steudler P, Melillo J, 1989. Nitrogen saturation in northern forest ecosystems. Bioscience 39:378386.

Aherne J, Mongeon A, Watmough SA, 2010. Temporal and spatial trends in precipitation chemistry in the Georgian Basin, British Columbia. J. Limnol. 69(Suppl.1):4-10.

Barbieri A, Mosello R, 2000. Recent trends in chemistry and mass budget of a high altitude lake in the southern Alps (Laghetto Inferiore, Canton Ticino, Switzerland). J. Limnol. 59:103-112.

Basart S, Pérez C, Nickovic S, Cuevas E, Baldasano JM, 2012. Development and evaluation of the BSC-DREAM8b dust regional model over Northern Africa, the Mediterranean and the Middle East. Tellus B 64:18539.

Battarbee RW, Kernan M, Rose N, 2009. Threatened and stressed mountain lakes in Europe: assessment and progress. Aquat. Ecosyst. Health 12:118-129.
Brancelj A, 2002. High-mountain lakes in the eastern part of the Julian Alps. ZRC Publ., Ljubljana: 266 pp.

Camarero L, Rogora M, Mosello R, Anderson NJ, Barbieri A, Botev I, Kernan M, Kopacek J, Korhola A, Lotter AF, Muri G, Postolache C, Stuchlik E, Thies H, Wright RF, 2009. Regionalisation of chemical variability in European mountain lakes. Freshwater Biol. 54:2452-2469.

Camarero L, Wright RF, Catalan J, Ventura M, 2004. Application of MAGIC to Lake Redó (Central Pyrenees): an assessment of the effects of possible climate driven changes in atmospheric precipitation, base cation deposition and weathering rates on lake water chemistry. J. Limnol. 63:123-132.

Civerolo K, Brankov E, Rao ST, Roy K, Lewis P, Galvin P, 2003. Analysis of ambient, precipitation-weighted, and lake sulfate concentrations in the Adirondack region of New York. Environ. Pollut. 123:337-345.

Clow DW, Sickman JO, Striegl RG, Krabbenhoft DP, Elliot JG, Dornblaser M, Roth DA, Campbell DH, 2003. Changes in the chemistry of lakes and precipitation in high-elevation national parks in the western United States, 1985-1999. Water Resour. Res. 39:1171-1183.

Dise NB, Wright RF, 1995. Nitrogen leaching in European forests in relation to nitrogen deposition. Forest Ecol. Manag. 71:153-162.

EEA, 2012. European Union emission inventory report 19902010 under the UNECE convention on long-range transboundary air pollution (LRTAP). European Environmental Agency Technical report, No 8/2012. European Environment Agency Publ., Copenhagen: 148 pp.

ICP Waters, 2003. The 15-year report: assessment and monitoring of surface waters in Europe and Nort America; acidification and recovery, dynamic modelling and heavy metals. ICP Waters report 73/2003. ICP Waters. Norwegian Institute for Water Research Publ., Oslo: $111 \mathrm{pp.}$

ISO, 1985. Water quality. Determination of electrical conductivity. Norm ISO 7888:1985. International Organization for Standardization Publ., Geneva: 6 pp.

ISO, 1994. Water quality. Determination of $\mathrm{pH}$. Norm ISO 10523:1994. International Organization for Standardization Publ., Geneva: 13 pp.

ISO, 1998. Water quality. Determination of dissolved $\mathrm{Li}+, \mathrm{Na}+$, $\mathrm{NH} 4+, \mathrm{K}+, \mathrm{Mn} 2+, \mathrm{Ca} 2+, \mathrm{Mg} 2+, \mathrm{Sr} 2+$ and $\mathrm{Ba} 2+$ using ion chromatography. Method for water and waste water. Norm ISO 14911:1998. International Organization for Standardization Publ., Geneva: 18 pp.

ISO, 2007. Water quality. Determination of dissolved anions by liquid chromatography of ions. 1 . Determination of bromide, chloride, fluoride, nitrate, nitrite, phosphate and sulfate. Norm ISO 10304-1:2007. International Organization for Standardization Publ., Geneva: 15 pp.

Kastelec D, 1999. [Use of universal kriging for objective spatial interpolation of average yearly precipitation in Slovenia]. [Article in Slovenian]. Res. Rep. Biotech. Fac. Univ. Ljublj. Agric. 73:301-314.

Kopacek J, Stuchlik E, Wright RF, 2005. Long-term trends and spatial variability in nitrate leaching from alpine catchmentlake ecosystems in the Tatra Mountains (Slovakia-Poland). Environ. Pollut. 136:89-101.

Lehmann CMB, Bowersox VC, Larson SM, 2005. Spatial and 
temporal trends of precipitation chemistry in the United States, 1985-2002. Environ. Pollut. 135:347-361.

Marchetto A, Mosello R, Rogora M, Manca M, Boggero A, Morabito G, Musazzi S, Tartari GA, Nocentini AM, Pugnetti A, Bettinetti R, Panzani P, Armiraglio M, Cammarano P, Lami A, 2004. The chemical and biological response of two remote mountain lakes in the Southern Central Alps (Italy) to twenty years of changing physical and chemical climate. J. Limnol. 63:77-89.

Marchetto A, Rogora M, Arisci S, 2013. Trend analysis of atmospheric deposition data: a comparison of statistical approaches. Atmos. Environ. 64:95-102.

Momen B, Lawrence GB, Nierzwicki-Bauer SA, Sutherland JW, Eichler LW, Harrison JP, Boylen CW, 2006. Trends in summer chemistry linked to productivity in lakes recovering from acid deposition in the Adirondack region of New York. Ecosystems 9:1306-1317.

MOP, 2003a. [Report on the state of the environment in Slovenia in 2002]. [Book in Slovenian]. Ministry of the Environment, Spatial Planning and Energy, Republic of Slovenia Publ., Ljubljana.

MOP, 2003b. [Water wealth of Slovenia]. [Book in Slovenian]. Ministry of the Environment, Spatial Planning and Energy, Republic of Slovenia Publ., Ljubljana: 131 pp.

Mosello R, Brizzio MC, Kotzias D, Marchetto A, Rembges D, Tartari G, 2002. The chemistry of atmospheric deposition in Italy in the framework of the National Programme for Forest Ecosystems Control (CONECOFOR). J. Limnol. 61(Suppl.1):77-92.

Muri G, 2004. Physico-chemical characteristics of lake water in 14 Slovenian mountain lakes. Acta Chim. Slov. 51:257-272.

Muri G, Brancelj A, 2003. Seasonal water chemistry variations in three Slovenian mountain lakes. Acta Chim. Slov. 50:137147.

Rogora M, Massaferro J, Marchetto A, Tartari G, Mosello R, 2008. The water chemistry of some shallow lakes in Northern Patagonia and their nitrogen status in comparison with remote lakes in different regions of the globe. J. Limnol. 67:75-86.

Rogora M, Mosello R, Arisci S, Brizzio MC, Barbieri A, Balestrini R, Waldner P, Schmitt M, Stähli M, Thimonier A, Kalina M, Puxbaum H, Nickus U, Ulrich E, Probst A, 2006. An overview of atmospheric deposition chemistry over the Alps: present status and long-term trends. Hydrobiologia 562:17-40.

SEA, 2006. [Climate conditions in Slovenia for the period 1971-
2000]. [Book in Slovenian]. Slovenian Environment Agency Publ., Ljubljana: 28 pp.

Skjelkvåle BL, Stoddard JL, Jeffries DS, Torseth K, Hogåsen T, Bowman J, Mannio J, Montheith DT, Mosello R, Rogora M, Rzychon D, Vesely J, Wieting J, Wilander A, Worsztynowicz A, 2005. Regional scale evidence for improvements in surface water chemistry 1990-2001. Environ. Pollut. 137:165176.

Stoddard JL, Traaen TS, Skjelkvåle BL, 2001. Assessment of nitrogen leaching at ICP-Waters sites (Europe and North America). Water Air Soil Poll. 130:781-786.

Tait D, Thaler B, 2000. Atmospheric deposition and lake chemistry trends at a high mountain site in the eastern Alps. J. Limnol. 59:61-71.

Talbot MR, 2001. Nitrogen isotopes in paleolimnology, p. 401439. In: W.M. Last, J.P. Smol (eds.), Tracking environmental change using lake sediments. 2. Physical and geochemical methods. Kluwer Academic Publishers.

Traaen TS, Stoddard JL, 1995. An assessment of nitrogen leaching from watersheds included in ICP on waters. ICP Waters report 86001/1995. ICP Waters. Norwegian Institute for Water Research Publ., Oslo: 39 pp.

UBA, 2004. Manual on methodologies and criteria for modelling and mapping critical loads \& levels and air pollution effects, risks and trends. Federal Environmental Agency (Umweltbundesamt) Publ., Berlin: 266 pp.

Vreča P, Muri G, 2006. Changes in accumulation of organic matter and stable carbon and nitrogen isotopes in sediments of two Slovenian mountain lakes (Lake Ledvica and Lake Planina), induced by eutrophication changes. Limnol. Oceanogr. 51:781-790.

Vreča P, Muri G, 2010. Sediment organic matter in mountain lakes of north-western Slovenia and its stable isotopic signatures: records of natural and anthropogenic impacts. Hydrobiologia 648:35-49.

WMO GAW, 2004. Manual for the GAW precipitation chemistry programme. WMO TD No. 1251. World Meteorological Organization, Global Atmosphere Watch Publ., Geneva: 170 pp.

Wright RF, Cosby BJ, 2003. Future recovery of acidified lakes in southern Norway predicted by the MAGIC model. Hydrol. Earth Syst. Sc. 7:467-483.

Wright RF, Emmett BA, Jenkins A, 1998. Acid deposition, landuse change and global change: MAGIC 7 model applied to Aber, UK (NITREX project) and Risdalsheia, Norway (RAIN and CLIMEX projects). Hydrol. Earth Syst. Sc. 2:385-397. 